\title{
FERTILITY DETERMINANTS IN INDONESIA: ANALYSIS OF INDONESIAN BASIC HEALTH SURVEY YEAR 2017
}

\author{
Philipus Prihantiko Kurniagung1), Vitri Widyaningsih²)
}

\author{
${ }^{1)}$ Masters Program in Public Health, Universitas Sebelas Maret \\ 2)Faculty of Medicine, Universitas Sebelas Maret
}

\begin{abstract}
Background: The current fertility rate for Indonesia in 2020 is 2.28 births per woman. High fertility, particularly when it involves conception either too early or too late in the fertility cycle or when short birth intervals are involved, is known to pose higher risks for both mothers and infants. This study aimed to investigate fertility determinants in Indonesia.

Subjects and Method: A cross-sectional study was carried out using Indonesian basic health survey year 2017. A sample of 34,199 women of reproductive age aged 15-49 years was selected for this study. The dependent variable was live birth children. The independent variables were education, knowledge toward contraception, employment status, literacy, family discussion, health insurance membership, child birth last year, contraceptive method, residence, province, and source of information. The data were analyzed by a multiple logistic regression.

Results: The likelihood of women to have children $>2$ increased with low education $(\mathrm{OR}=2.67$; $95 \% \mathrm{CI}=2.53$ to $2.81 ; \mathrm{p}<0.001)$, low literacy $(\mathrm{OR}=1.59 ; 95 \% \mathrm{CI}=1.44$ to $1.75 ; \mathrm{p}<0.001)$, and no family discussion $(\mathrm{OR}=1.2 ; 95 \% \mathrm{CI}=1.13$ to $1.24 ; \mathrm{p}<0.001)$. The likelihood of women to have children $>2$ decreased with no health insurance membership ( $\mathrm{OR}=0.73$; 95\% $\mathrm{CI}=0.69$ to 0.76 ; $\mathrm{p}<0.001)$, use contraception $(\mathrm{OR}=0.33 ; 95 \% \mathrm{CI}=0.31$ to $0.34 ; \mathrm{p}<0.001)$, child birth delivery last year $(\mathrm{OR}=0.77 ; 95 \% \mathrm{CI}=0.71$ to $0.83 ; \mathrm{p}<0.001)$, lived in province in West Indonesia $(\mathrm{OR}=$ $0.69 ; 95 \% \mathrm{CI}=0.66$ to $0.72 ; \mathrm{p}<0.001)$, received information from private agency $(\mathrm{OR}=0.83$; $95 \% \mathrm{CI}=0.78$ to $0.89 ; \mathrm{p}<0.001$ ), and worked ( $\mathrm{OR}=0.72 ; 95 \% \mathrm{CI}=0.69$ to $0.75 ; \mathrm{p}<0.001)$.

Conclusion: The likelihood of women to have children $>2$ increases with low education, low literacy, and no family discussion. The likelihood of women to have children $>2$ decreases with no health insurance membership, use contraception, child birth delivery last year, lived in province in West Indonesia, received information from private agency, and worked.
\end{abstract}

Keywords: fertility, women of reproductive age, demography

\section{Correspondence:}

Philipus Prihantiko Kurniagung. Masters Program in Public Health, Universitas Sebelas Maret. Jl. Ir. Sutami 36A, Surakarta 57126, Central Java. Email: prihantiko@gmail.com. Mobile: o89688103450.

The $7^{\text {th }}$ International Conference on Public Health

Solo, Indonesia, November 18-19, 2020 | 300

https://doi.org/10.26911/the7thicph.03.120 